\title{
THORACIC EPIDURAL VERSUS INTRAVENOUS PATIENT-CONTROLLED ANALGESIA AFTER OPEN COLORECTAL CANCER SURGERY
}

\author{
Dragana Radovanović ${ }^{1,2}$,Zoran Radovanovići, ${ }^{1,3}$, Svetlana Škorić-Jokić ${ }^{2}$ Milanka Tatić ${ }^{1,2}$, \\ Aljoša Mandić ${ }^{1}$ and Tatjana Ivković-Kapicl ${ }^{1}$ \\ ${ }^{1}$ School of Medicine, University of Novi Sad, Novi Sad; \\ ${ }^{2}$ Department of Anesthesiology and Intensive Care, \\ ${ }^{3}$ Department of Surgical Oncology, Oncology Institute of Vojvodina, Sremska Kamenica, Serbia
}

SUMMARY - The aim of the study was to compare thoracic epidural analgesia (TEA) and intravenous patient-controlled analgesia (IV-PCA) after open colorectal cancer surgery. This prospective study included sixty patients scheduled for elective open colorectal surgery and randomized to either postoperative IV-PCA with morphine $(\mathrm{n}=30)$ or TEA with a mixture of levobupivacaine, fentanyl and adrenaline $(n=30)$. The primary outcome was return of bowel function. The secondary outcome was quality of postoperative analgesia at rest, on coughing and during mobilization. Intermediate outcomes included patient satisfaction, time out of bed, rate of side effects and postoperative complications, and time of discharge. Recovery of postoperative ileus occurred sooner $(p<0.001)$ and resumption of dietary intake was achieved earlier $(\mathrm{p}<0.001)$ in TEA group. Intensity of pain during the first 3 postoperative days was significantly lower at rest, on coughing and during mobilization $(p<0.001)$, and mobilization was much more efficient $(\mathrm{p}<0.005)$ in TEA than in IV-PCA group. Satisfaction scores were better in TEA group $(\mathrm{p}<0.001)$. Nausea, sedation and postoperative delirium occurred less frequently in TEA group ( $p<0.05, p<0.001$ and $p<0.05$, respectively). TEA demonstrated significantly better effectiveness than IV-PCA after open colorectal cancer surgery and had a positive impact on bowel function, dietary intake, patient satisfaction and early mobilization. The results of this study demonstrated the importance of implementation of TEA as a preferred method for postoperative pain control after major open colorectal surgery.

Key words: Analgesia, epidural; Analgesia, patient-controlled; Colorectal surgery

\section{Introduction}

Open colorectal surgery induces severe and prolonged postoperative pain, especially during mobilization, which does not only reduce comfort but can also lead to serious local and systemic complications. Ineffective postoperative analgesia after colorectal surgery has been found to prolong postoperative ileus, immo-

Correspondence to: Dragana Radovanovic, $M D, P h D$, Oncology Institute of Vojvodina, Department of Anesthesiology and Intensive Care, Put dr Goldmana 4, 21204 Sremska Kamenica, Serbia

E-mail: dragana.radovanovic@mf.uns.ac.rs; radovdragana@gmail.com

Received September 7, 2016, accepted February 2, 2017 bilization, sleep disorders and fatigue, and may delay hospital discharge ${ }^{1}$.

Thoracic epidural analgesia (TEA) is the gold standard for providing analgesia after open colorectal surgery. Data from numerous randomized controlled studies and meta-analysis show that compared with other analgesia techniques, epidural analgesia (EA) provides superior pain control after open colorectal surgery ${ }^{2-4}$. EA also reduces postoperative mortality and improves a multitude of cardiovascular, respiratory and gastrointestinal morbidity endpoints ${ }^{5}$, decreases duration of postoperative ileus ${ }^{3,4,6}$, reduces postoperative surgical stress ${ }^{7}$, and improves clinical outcomes ${ }^{8}$, 
functional recovery ${ }^{9}$ and perioperative quality of life $^{10}$. Few clinical investigations of EA during colorectal cancer surgery showed that EA could reduce the chance of cancer metastasis and provide better overall survival ${ }^{11-13}$.

The use of EA after colorectal resections is well established in hospitals of central and northern Europe. The survey by Hasanberg et al. has shown that EA is routinely used in 74\% of Austrian and 78\% of German hospitals after colorectal resections ${ }^{14,15}$. In northern Europe, over $85 \%$ of anesthesiologists use EA routinely in standard colorectal cancer operations ${ }^{16}$. Despite the concepts of perioperative pain management and advances in the knowledge of TEA after major colorectal surgery, TEA is rarely used for postoperative pain control in clinical settings in southeast Europe. Intravenous (iv) boluses of opioids remain the most common treatment of intensive postoperative pain in some countries, so a large number of patients still suffer from unacceptable pain after surgery.

The purpose of our study was to compare TEA and intravenous patient-controlled analgesia (IV-PCA) after open colorectal cancer surgery and to evaluate recovery of gastrointestinal function, nutritional intake, pain intensity, patient satisfaction, time out of bed, rate of postoperative complications and side effects, and length of hospital stay. By reviewing our own practices, our objective is to identify and promote the more effective pain strategies within our own resources.

\section{Patients and Methods}

We performed a prospective, randomized, controlled clinical study in adult patients undergoing elective open colorectal resection at Oncology Institute of Vojvodina in Sremska Kamenica. Sixty colorectal cancer patients were randomized to either postoperative IV-PCA with morphine $(n=30)$ or TEA with a mixture of levobupivacaine, fentanyl and adrenaline $(n=30)$. The study was approved by the institutional ethics committee.

Inclusion criteria were the American Society of Anesthesiologists (ASA) physical status I-III, signed informed consent to participate in the study, and elective open colorectal cancer surgery performed. Exclusion criteria included contraindication to placement of an epidural catheter and use of nonsteroidal anti-inflammatory drugs (NSAIDs), history of allergy to lo- cal anesthetics, NSAIDs or opioids, alcohol or drug abuse, pregnancy, palliative surgery, patient refusal and inability to communicate or understand the purpose of the study.

\section{Preoperative care}

Patients received standardized instructions about the surgical procedure, perioperative program, and written and verbal instructions for use of IV-PCA and TEA. All 60 patients agreed to participate in the study. After obtaining their informed written consent to participate in the study, randomization was carried out by permuted-block randomization where the block size was four (patients were randomized to either postoperative IV-PCA with morphine or TEA with a mixture of levobupivacaine, fentanyl and adrenaline). Although the patients were not blinded, they were not aware of the study hypothesis, and both IV-PCA and TEA groups were equally attractive to them.

Routine mechanical bowel preparation consisted of a clear liquid diet and polyethylene glycol electrolyte lavage solution performed 2 days before surgery. Prophylactic antibiotics were administered (metronidazole $3 \times 400 \mathrm{mg}$, orally on the day before surgery and metronidazole $500 \mathrm{mg}$ and cefazolin $1 \mathrm{~g}$, iv $30 \mathrm{~min}$ before the skin incision). In the evening before surgery, all patients received once-daily subcutaneous dose of low-molecular-weight heparin (0.4 $\mathrm{mL}$ nadroparin) for prevention of venous thromboembolism.

All operations were performed in the morning hours by the same surgical and anesthesiological team. No premedication was administered.

\section{The TEA group}

In the TEA group, epidural block was established before general anesthesia, epidural catheters were placed between the T8 and T12 interspaces. If there were no signs of intravascular or intrathecal catheter position, levobupivacaine $0.5 \%$ was injected through the epidural catheter in divided doses to a maximum of $0.1-0.15 \mathrm{~mL} / \mathrm{kg}$ to produce bilateral segmental sensory block to ice and pinprick between $\mathrm{T} 4$ and $\mathrm{S} 5$ dermatomes. Neural blockade was maintained during surgery with additional $5 \mathrm{~mL}$ of levobupivacaine $0.25 \%$ administered hourly.

Light general anesthesia included induction with propofol $2-2.5 \mathrm{mg} / \mathrm{kg}$, fentanyl $100 \mu \mathrm{g}$, atracurium 0.5 
$\mathrm{mg} / \mathrm{kg}$ and maintenance with $0.6 \%-0.8 \%$ end-tidal isoflurane as needed to treat evidence of inadequate anesthesia and to maintain arterial blood pressure (BP) and heart rate (HR) within $30 \%$ of preoperative baseline values. Muscle relaxation was provided by an injection of atracurium using train-of-four monitoring. Patients were ventilated with a $50 \%$ oxygen/air mixture.

Epidural infusion of levobupivacaine $1 \mathrm{mg} / \mathrm{mL}$ with fentanyl $3 \mu \mathrm{g} / \mathrm{mL}$ and adrenaline $2 \mu \mathrm{g} / \mathrm{mL}$ at a rate between 5 and $10 \mathrm{~mL} / \mathrm{h}$ was started at the end of surgery and continued for up to postoperative day (POD) 3.

The segmental sensory level of analgesia was assessed $4 \mathrm{~h}$ after the end of surgery and then twice daily by the acute pain team, and the infusion was adjusted to maintain sensory block between T7 and L3. If the visual analog scale (VAS; 0-10 cm) at rest was greater than 5 , the rate of infusion was increased to a maximum of $15 \mathrm{~mL} / \mathrm{h}$ or the concentration of levobupivacaine increased to $2 \mathrm{mg} / \mathrm{mL}$ with the infusion rate decreased to $8 \mathrm{~mL} / \mathrm{h}$. If epidural block did not provide adequate analgesia, the patient continued to be included in the intention-to-treat analysis, but was excluded from the study. Neurologic profile was performed on a daily basis to assess sensory and motor deficit. The epidural site was inspected for signs of infection.

\section{The IV-PCA group}

In the IV-PCA group, patients received general anesthesia consisting of propofol $2-2.5 \mathrm{mg} / \mathrm{kg}, 200 \mu \mathrm{g}$ fentanyl, atracurium $0.5 \mathrm{mg} / \mathrm{kg}$ and $1 \%-1.4 \%$ endtidal isoflurane, as needed to treat evidence of inadequate anesthesia and to maintain $\mathrm{BP}$ and $\mathrm{HR}$ within $30 \%$ of preoperative baseline values. Muscle relaxation was provided by an injection of atracurium using trainof-four monitoring. Patients were ventilated with a $50 \%$ oxygen/air mixture.

On arrival to the Intensive Care Unit (ICU), patients received a bolus of iv morphine $(5 \mathrm{mg})$, and PCA device (CADD-Legacy PCA Model 6300, SIMS Deltec, Inc., St. Paul, Minnesota, USA) was then connected. The rate of infusion of iv morphine was set up at a bolus dose of 1-2 mg, lockout interval of $8 \mathrm{~min}$, $\max 3$ doses/h, with no background infusion. If VAS at rest was greater than 5 , the lockout interval was reduced to 6 minutes, $\max 4$ doses $/ \mathrm{h}$. If inadequate analgesia persisted, the bolus dose was increased in 0.5 $\mathrm{mg}$ increments every second hour. PCA was discontinued on POD 3.

\section{Postoperative care}

Clinical examination was performed twice a day on the first 4 POD. Safety variables such as degree of sedation, respiratory rate, $\mathrm{HR}, \mathrm{BP}, \mathrm{SpO}_{2}$ and body temperature were closely monitored. Routine laboratory tests were taken throughout the study. Oxygen therapy (30\%, nasal catheter) was provided to all patients during the first $24 \mathrm{~h}$.

Nasogastric tubes (NGT) were removed on the morning after surgery. From then, patients were offered clear or full liquids. Patients were allowed only sips of water on POD 1, and a full fluid diet was offered to both groups on POD 2. The protocol specified that metoclopramide was the preferred antiemetic medication. Prophylactic antiemetic treatment was not permitted. In case of protracted vomiting, ileus and distended abdomen, the diet was discontinued and iv fluids were provided. Antinausea and vomiting therapy was administered, and NGT was inserted to decompress the stomach.

Ketorolac iv was given to both groups as a supplementary analgesic. The first dose $(30 \mathrm{mg})$ was administered on patient arrival at the ICU. Ketorolac $15 \mathrm{mg}$ was subsequently administered three times per day for $72 \mathrm{~h}$. After $72 \mathrm{~h}$, patients received oral ibuprofen 400 $\mathrm{mg}$ four times per day until discharge or up to POD 6.

All patients in both groups were encouraged, but not forced, by the ward nurse to mobilize by sitting in a chair and walking from POD 1.

Data were collected daily (at 8 AM, 12 AM, and 8 PM during the first 3 POD) by a research assistant unaware of the hypothesis to be tested. Patient bowel function (time to first bowel movement), food intake, quality of analgesia at rest, on coughing and during mobilization (VAS; $0-10 ; 0=$ no pain and $10=$ the worst imaginable pain), patient satisfaction with postoperative analgesia (excellent $=3$, good $=2$, fair $=1$, poor $=0$ ); sedation scores (wide awake $=0$; mildly sleepy and responsive to verbal command $=1$; moderately sleepy and responsive to nociceptive stimulation $=2$; extremely sleepy and unresponsive to nociceptive stimulation $=3$ ), time out of bed, either sitting or walking, perioperative complication rate, side effects (hypotension, bradycardia, nausea, vomiting, pruritus, respiratory depression), and readiness for discharge 
were recorded. In TEA group, the segmental sensory level of analgesia and motor block (Bromage scale; 1 = no motor block, $2=$ knee blocked and mobility of ankle preserved, 3 = mobility of ankle difficult, $4=$ knee and ankle blocked) were assessed. Postoperative complications were fully documented and diagnosed according to clinical and laboratory criteria. Treatment for perioperative complications was standardized. Postoperative delirium was diagnosed with the Confusion Assessment Method (CAM) and Diagnostic and Statistical Manual of Mental Disorders, fourth edition criteria for delirium.

Patients were visited each morning by the surgical team that was responsible for patient postoperative care and was unaware of the results of clinical or objective assessments.

\section{Results}

\section{Perioperative anesthesia and surgical care}

All enrolled patients completed the study. Demographic characteristics and clinical data related to preoperative health status were similar in the two groups (Table 1). There was no significant difference between the two groups in terms of type and duration of surgery, amount of blood loss and blood transfused, and length of hospital stay (Table 2).

Intraoperative complications occurred in the same number of patients in the two groups (TEA group - 3 patients with hypotension and 1 patient with bradycardia; and IV-PCA group - 1 patient with ventricular extrasystoles, 2 patients with bradycardia and 1 patient with hypotension).

There was no significant between-group difference according to postoperative complications except for postoperative delirium. The incidence of postoperative delirium requiring pharmacological intervention was significantly greater in IV-PCA group during 3 POD (Table 2). There were no epidural failures (dislodgement, leak, disconnection) during the intraoperative and postoperative period.

\section{Gastrointestinal function}

Recovery of postoperative ileus occurred sooner in TEA group. Bowel movements were reestablished in the first $48 \mathrm{~h}$ in $86.7 \%$ of patients in TEA group and in $36.7 \%$ of patients in IV-PCA group ( $<<0.001)$. The
Table 1. Demographic characteristics

\begin{tabular}{|c|c|c|c|}
\hline Variable & $\begin{array}{l}\text { IV-PCA group } \\
(\mathrm{n}=30)\end{array}$ & $\begin{array}{l}\text { TEA group } \\
(\mathrm{n}=30)\end{array}$ & $\mathrm{p}$ value \\
\hline $\begin{array}{l}\text { Age, mean } \\
\text { (years) }\end{array}$ & $64.18 \pm 9.90$ & $65.88 \pm 10.00$ & NS \\
\hline Sex: & & & NS \\
\hline male & 18 & 20 & \\
\hline female & 12 & 10 & \\
\hline ASA & & & NS \\
\hline I & 4 & 2 & \\
\hline II & 13 & 16 & \\
\hline III & 13 & 12 & \\
\hline IV & 0 & 0 & \\
\hline $\begin{array}{l}\text { Preoperative } \\
\text { albumin } \\
(\mathrm{g} / \mathrm{L})\end{array}$ & $40.627 \pm 9.308$ & $39.767 \pm 6.626$ & NS \\
\hline $\begin{array}{l}\text { Preoperative } \\
\text { hematocrit } \\
(\%)\end{array}$ & $36.2 \pm 6.9$ & $36.7 \pm 6.5$ & NS \\
\hline
\end{tabular}

Values are mean \pm standard deviation or median ( $95 \%$ confidence interval); statistical tests included Student's t-test for parametric variables or Pearson $\chi^{2}$-test for categorical variables; $\mathrm{PCA}=\mathrm{pa}-$ tient-controlled anesthesia; TEA = thoracic epidural anesthesia; ASA = American Society of Anesthesiologists status; NS = nonsignificant

mean time from surgery to first bowel movements was $26.80 \pm 4.916 \mathrm{~h}$ in TEA group and $42.60 \pm 11.723 \mathrm{~h}$ in IV-PCA group. This difference reached statistical significance $(\mathrm{t}=-6.808 ; \mathrm{p}=0.000)$.

Similarly, resumption of dietary intake was achieved earlier $(\mathrm{p}<0.05)$ in TEA group. In TEA group, 10 (33.3\%) patients started with semisolid food in the first $48 \mathrm{~h}$ and the remaining $20(66.7 \%)$ in $72 \mathrm{~h}$ after surgery. This is in contrast with PCA group, where 10 (33.3\%) patients started with semisolid food in the first $72 \mathrm{~h}, 18(60 \%)$ in $96 \mathrm{~h}$, and $2(6.7 \%)$ patients no sooner than $120 \mathrm{~h}$.

\section{Postoperative pain relief and satisfaction scores}

Pain intensity was significantly lower at rest, on coughing and during mobilization in TEA group compared with IV-PCA group during the first 3 POD ( $p<0.001)$ (Figs. 1-3). Satisfaction scores were significantly better in TEA group compared with IV-PCA group during the first 3 POD $(p<0.001)$ (Table 3). 
Table 2. Surgical and hospital processes in the two study groups

\begin{tabular}{|l|l|l|l|}
\hline Variable & IV-PCA group $(\mathrm{n}=30)$ & TEA group $(\mathrm{n}=30)$ & $\mathrm{p}$ \\
\hline Type of surgery: & & & NS \\
\hline right hemicolectomy & 5 & 4 & \\
\hline left hemicolectomy & 2 & 2 & \\
\hline sigmoid resection & 4 & 4 & \\
\hline low anterior resection & 13 & 14 & \\
\hline abdominoperineal resection & 5 & 5 & \\
\hline Hartmann resection & 1 & 1 & NS \\
\hline Duration of surgery (min) & $130.50 \pm 28.538$ & $141.50 \pm 31.735$ & NS \\
\hline Blood loss (mL) & $343.33 \pm 222.344$ & $313.33 \pm 216.131$ & NS \\
\hline Transfusion (patients) & 6 & 6 & NS \\
\hline Intraoperative complications & 4 & 4 & \\
\hline Postoperative complications & & & NS \\
\hline Ileus & 0 & 1 & NS \\
\hline Perineal infection & 0 & 1 & NS \\
\hline Pleural effusion & 2 & 0 & NS \\
\hline Distended abdomen & 1 & 0 & $\mathrm{p}=0.01$ \\
\hline Postoperative delirium & 6 & 0 & NS \\
\hline Length of hospital stay (days) & $9.23 \pm 1.794$ & $9.13 \pm 2.501$ & \\
\hline
\end{tabular}

Values are mean \pm standard deviation or median (95\% confidence interval); statistical tests included Student's t-test for parametric variables or Pearson $\chi^{2}$-test for categorical variables; PCA = patient-controlled anesthesia; TEA = thoracic epidural anesthesia; NS = nonsignificant

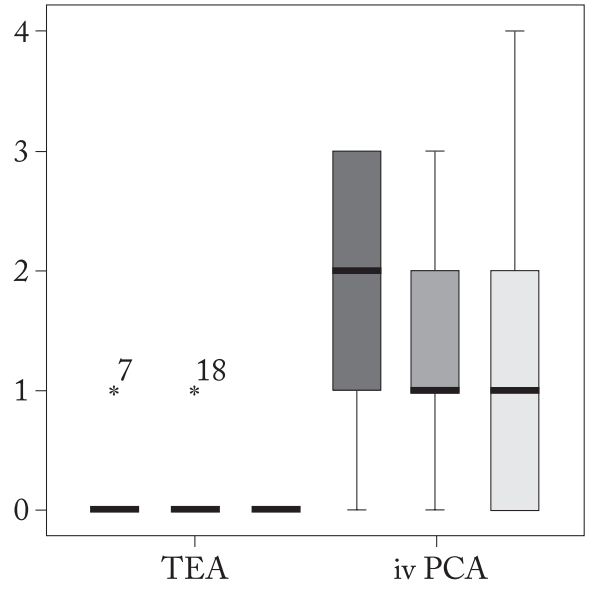

VAS = visual analog scale POD = postoperative day Fig. 1. Comparison of visual analog scale (VAS) at rest between thoracic epidural (TEA) and intravenous patient-controlled (IV-PCA) groups on the first three postoperative days.

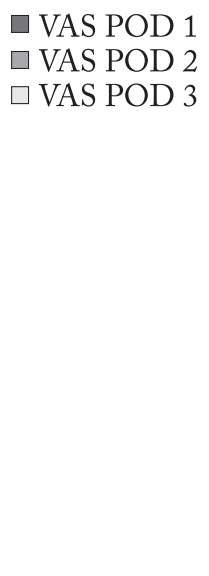

VAS POD 1

$\square$ VAS POD 2

$\square$ VAS POD 3
VAS = visual analog scale; $\mathrm{POD}=$ postoperative day

Fig. 2. Comparison of visual analog scale (VAS) on coughing between thoracic epidural (TEA) and intravenous patient-controlled (IV-PCA) group on the first three postoperative days. 


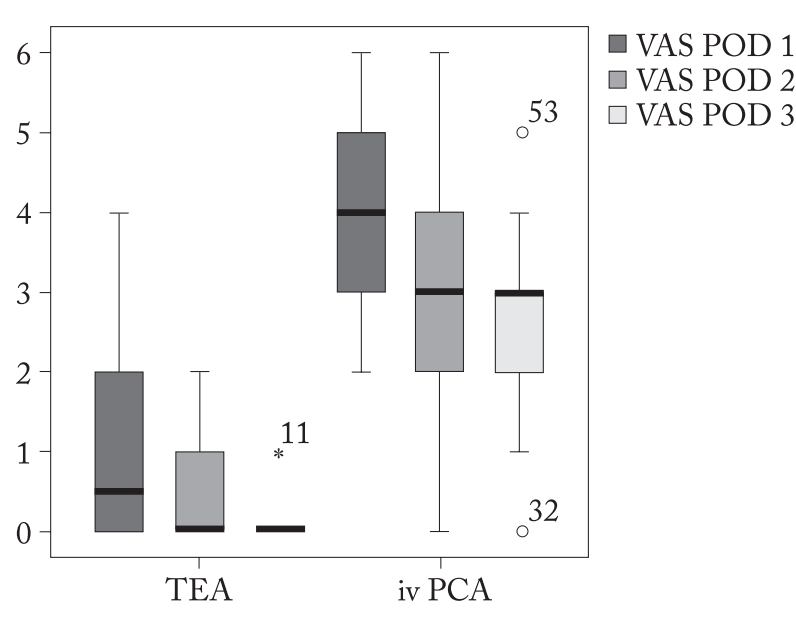

VAS = visual analog scale POD = postoperative day

Fig. 3. Comparison of visual analog scale (VAS) on walking between thoracic epidural (TEA) and intravenous patient-controlled (IV-PCA) group on the first three postoperative days.

\section{Postoperative time out of bed}

Mobilization was much more efficient in TEA group than in IV-PCA group ( $\mathrm{p}<0.005)$ (Figs. 4 and 5).

\section{Side effects}

There was no significant difference between the two groups in terms of side effects, except for nausea and sedation. The incidence of nausea was significantly greater in IV-PCA group during POD 1. The levels of sedation were significantly lower in TEA group compared with IV-PCA group during the first 3 POD $(\mathrm{p}<0.001)$. The Bromage score was 1 in all TEA patients during 3 POD.

\section{Discussion}

Pain, increased sympathetic tone, use of systemic opioid analgesia and intestinal neuroinflammatory processes negatively affect gastrointestinal motility and prolong the duration of postoperative ileus. According to the results of our study, recovery of postoperative ileus occurred significantly sooner in TEA group than in IV-PCA group. The mean time from surgery to bowel movements was $26.80 \pm 4.916 \mathrm{~h}$ in TEA group and $42.60 \pm 11.723 \mathrm{~h}$ in IV-PCA group $(\mathrm{p}<0.001)$.

Shortening the duration of postoperative ileus increases patient comfort and accelerates initiation of oral feeding. Resumption of dietary intake was achieved earlier $(p<0.05)$ in TEA group compared with IV-PCA group.

Earlier restoration of gastrointestinal function in TEA group recorded in our study is in agreement with most previous findings. Well designed randomized controlled trials have shown that TEA reduces duration of postoperative ileus compared with systemic opioid analgesia after open colorectal surgery ${ }^{4,6,10,17-19}$.

Table 3. Patient satisfaction scores

\begin{tabular}{|c|c|c|c|c|c|c|}
\hline \multirow{2}{*}{\multicolumn{2}{|c|}{ Satisfaction score }} & \multicolumn{2}{|c|}{ IV-PCA group $(n=30)$} & \multicolumn{2}{|c|}{ TEA group $(n=30)$} & \multirow{2}{*}{$p$ value } \\
\hline & & $\mathrm{n}$ & $\%$ & $\mathrm{n}$ & $\%$ & \\
\hline \multirow[t]{4}{*}{ POD 1} & Excellent & 8 & 26.7 & 27 & 90 & \multirow{4}{*}{$\mathrm{p}<0.001$} \\
\hline & Good & 20 & 66.7 & 3 & 10 & \\
\hline & Fair & 2 & 6.7 & 0 & 0 & \\
\hline & Poor & 0 & 0 & 0 & 0 & \\
\hline \multirow[t]{4}{*}{ POD 2} & Excellent & 7 & 23.3 & 30 & 100 & \multirow{4}{*}{$\mathrm{p}<0.00$} \\
\hline & Good & 22 & 73.3 & 0 & 0 & \\
\hline & Fair & 1 & 3.3 & 0 & 0 & \\
\hline & Poor & 0 & 0 & 0 & 0 & \\
\hline \multirow[t]{4}{*}{ POD 3} & Excellent & 12 & 40 & 30 & 100 & \multirow{4}{*}{$\mathrm{p}<0.001$} \\
\hline & Good & 17 & 56.7 & 0 & 0 & \\
\hline & Fair & 1 & 3.3 & 0 & 0 & \\
\hline & Poor & 0 & 0 & 0 & 0 & \\
\hline
\end{tabular}

Statistical test used was Mann-Whitney test; $\mathrm{POD}=$ postoperative day 


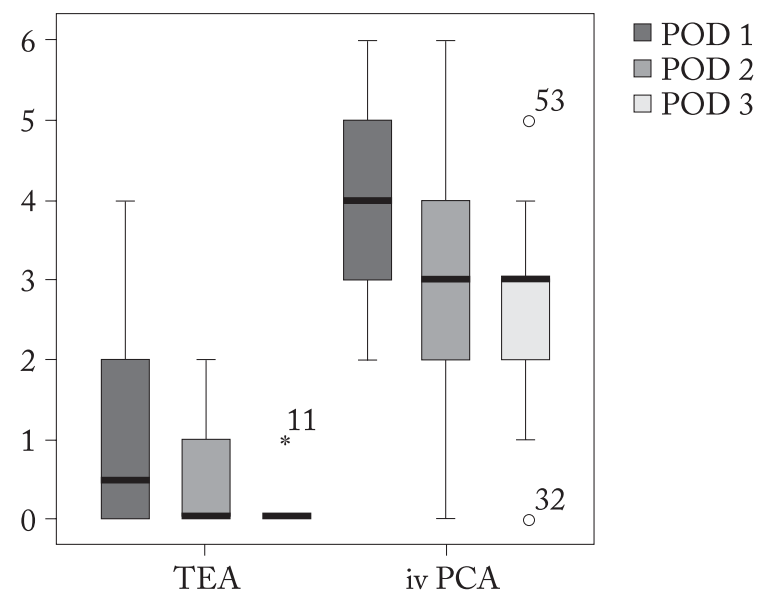

POD = postoperative day

Fig. 4. Comparison of time (min) patients spent sitting between thoracic epidural (TEA) and intravenous patient-controlled (IV-PCA) group on the first three postoperative days.

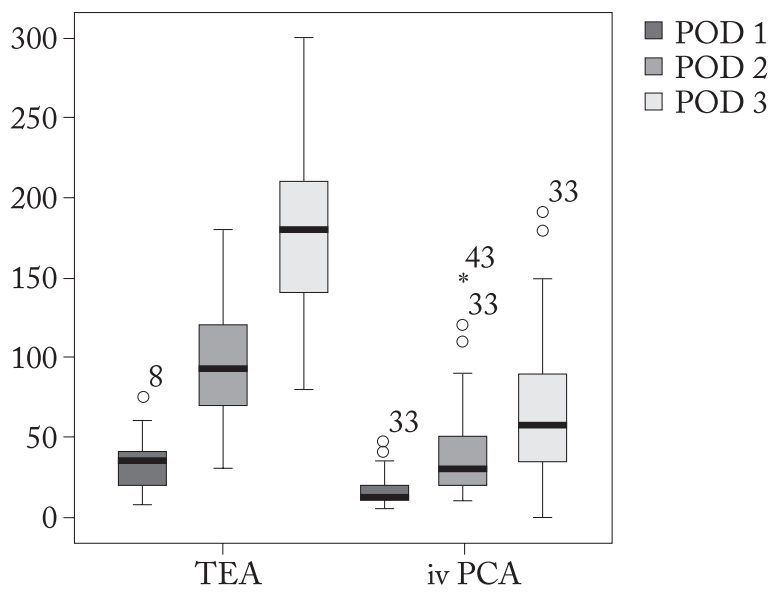

POD = postoperative day

Fig. 5. Comparison of time ( $\mathrm{min}$ ) patients spent walking between thoracic epidural (TEA) and intravenous patient-controlled (IV-PCA) group on the first three postoperative days.

Carli et al. ${ }^{4}$ investigated the effect of TEA on gastrointestinal function after colorectal surgery and their results showed that the mean time intervals from surgery to first flatus occurred earlier in patients with TEA compared with IV-PCA (1.9 \pm 0.6 days $v s$. $3.6 \pm 1.5$ days; $p<0.01)$. Basse et al. ${ }^{20}$ included EA with local anesthetic plus an opioid as part of an accelerated recovery program after colorectal surgery, also involving early oral feeding and mobilization, similar to our study. According to their results, bowel motions were reestablished within $48 \mathrm{~h}$ in $94 \%$ of patients after open sigmoidectomy ${ }^{21}$, and in 70\%-95\% after colonic resections $^{20}$. The mean time needed for establishment of gastrointestinal motility in our study was shorter than in either of the above surveys. In contrast, Paulsen et $a .^{22}$ conclude that TEA does not offer significant advantage over IV-PCA in return of bowel function.

Although a number of studies were examining the effects of EA on gastrointestinal motility after abdominal surgery during the last two decades, benefit such as better gastrointestinal function is likely but difficult to prove. Differences in study design, epidural drug regimens with or without opioids, technique of EA and surgical procedures complicate comparison and interpretation of data.

Results of meta-analyses showed that EA accelerated recovery of intestinal function after abdominal surgery, as well as subsets of studies in colorectal surgery $^{3,23}$. Faster resolution of postoperative ileus after major open surgery has been attributed to sympathetic block, superior pain therapy and reduced opioid consumption $^{6,24}$. Pain itself may inhibit bowel motility; many of the studies that found earlier recovery of bowel motility with EA also found that pain control was superior with $\mathrm{EA}^{4,6,25}$. Effective analgesia reduces the need for parenteral administration of opioids, thus avoiding their negative influence on peristalsis. Besides improving gastrointestinal function, TEA reduces the incidence of unpleasant symptoms such as nausea and vomiting, and thus accelerates the introduction of regular oral diet, which also accelerates gastrointestinal function recovery.

The goal of postoperative pain management is to reduce or eliminate pain and discomfort with a minimum of side effects. Provision of pain relief allows patients to cough, breathe deeply, allows early introduction of oral feeding and faster and more efficient mobilization. Effective analgesia has a potential to improve postoperative recovery and outcomes, and has long-lasting positive effects on functional capacity and quality of life of patients.

According to the results of our study, TEA with levobupivacaine, fentanyl and adrenaline provides significantly better analgesia compared to morphine IV-PCA. During the first 3 POD, pain intensity was significantly lower at rest, on coughing and during 
mobilization in TEA group compared with IV-PCA group ( $\mathrm{p}<0.001)$.

Epidural analgesia has been widely found to be the most effective method of pain relief, both at rest and on movement, after major surgical procedures ${ }^{19,26-28}$. The majority of studies involving open colorectal surgery $^{4,6,10,18,22}$ have reported that TEA with local anesthetics, with or without opioids, provides superior postoperative analgesia and reduces the frequency of moderate and intense pain, especially during mobilization compared with IV-PCA opioids. The addition of epidural opioid to epidural local anesthetic after major abdominal surgery has an adjunctive benefit compared with local anesthetic alone 6 . In contrast, results published by Zutshi et al. ${ }^{29}$ show that TEA offered no advantage over PCA for patients undergoing major intestinal resections, who are on a fast-track postoperative care plan.

The most common reason for dissatisfaction of $\mathrm{pa}^{-}$ tients is inadequate analgesia, so patient satisfaction has become an indicator of the quality of medical care. In our study, patients reported a high level of satisfaction with postoperative pain management. Patients in TEA group were significantly more satisfied with analgesia compared with patients in IV-PCA group during all 3 POD. In TEA group, 90\% of patients on POD 1 and 100\% on POD 2 and POD 3 rated analgesia as excellent. The results of most studies have shown that EA provides greater patient satisfaction with analgesia compared with parenteral opioids and improves the quality of life ${ }^{10,30}$. Carli et al. ${ }^{10}$ evaluated the quality of life using the SF-36 (The Short Form Health Survey) questionnaire in patients after elective colorectal surgery. They found that TEA provided superior quality of pain relief compared with IV-PCA, with long-lasting effects on exercise capacity and health-related quality of life. In contrast, according to Zutshi et al. ${ }^{29}$, TEA does not improve the quality of life compared to IV-PCA. Results of a meta-analysis published by Werawatganon et al. ${ }^{31}$ show that there was no significant difference in patient satisfaction with analgesia after intra-abdominal operations between patients receiving opioid IV-PCA and EA. Although the results of different studies vary, effective analgesia provided with TEA certainly increases patient satisfaction and improves the quality of life.

A beneficial effect of EA after colorectal surgery is optimal pain relief provided not only at rest but also during mobilization ${ }^{6}$. It made possible for the patients with EA to be out of bed for a greater period of time. Because of the relation between pain, gastrointestinal motility and mobilization, measuring the time spent out of bed was considered a key parameter in this study.

According to our results, patients with TEA were able to perform physical activity (sitting, standing and walking with support) during all 3 POD for a significantly longer time compared to patients with IV-PCA. Unfortunately, little data are available on the effect of mobilization on the speed and quality of recovery of patients after colorectal surgery, probably because analgesia is not always effective enough to be able to start early rehabilitation programs. According to the results of a study performed by Carli et al. ${ }^{10}$, during the first 4 POD patients with TEA spent between $2 \mathrm{~h}$ and $5 \mathrm{~h}$ out of bed, most of the time walking. In contrast, in the IV-PCA group, the value of VAS in motion was significantly higher and patients spent much of their time out of bed, sitting rather than walking. Basse et al. ${ }^{20}$ report on daily mobilization greater than $8 \mathrm{~h}$ on POD 1 in patients with TEA after colorectal surgery; however, it is not clear from their study how much of this activity was sitting or walking.

In the above studies, patients spent significantly more time out of bed than in our study. The reason could be the methods of work of our medical staff and even patients themselves. Patients sometimes were not ready to activate despite satisfactory analgesia and information about the benefits of early mobilization.

According to the results of our study, there were no significant differences between the groups in the incidence of side effects and perioperative complications except for nausea, sedation and postoperative delirium. Patients with TEA did not feel any weakness in their feet, nor recorded the presence of motor block.

In a study of a similar postoperative regimen with epidural local anesthetics, forced mobilization and early oral feeding, a significantly reduced feeling of fatigue was found in patients with TEA and there was no difference in the incidence of most side effects between EA and IV-PCA 6 6,10,17,18.

A large patient sample in the study performed by Flisberg et al. ${ }^{33}$ showed that patients with EA had better analgesia after major surgery with a reduced incidence of respiratory depression and sedation compared with patients with iv morphine analgesia. 
Our results correspond to the results of a metaanalysis published by Dolin et al. ${ }^{34}$, according which IV-PCA was associated with the highest incidence of nausea and higher levels of sedation compared with EA. The incidence of nausea in patients with IV-PCA was significantly higher than in our study. There was a significant decrease in the incidence of nausea and severe sedation over the time of analysis. The results of a meta-analysis published by Werawatganon et al. ${ }^{31}$ show that EA provides better analgesia than IV-PCA after abdominal surgery without differences in the incidence of other adverse effects.

The incidence of postoperative delirium requiring pharmacological intervention was significantly greater in IV-PCA group during the first 3 POD. Unfortunately, little data are available on the effect of perioperative analgesic technique on the rate of postoperative delirium. Mann et al. ${ }^{19}$ conclude that epidural local anesthetics with opioid improve mental status compared with IV-PCA. The study performed by Flisberg et al. ${ }^{33}$ showed that patients with EA were less confused compared with patients with iv morphine analgesia. The lower incidence of postoperative delirium in TEA group could be attributed to superior pain therapy and reduced opioid consumption, earlier recovery of postoperative ileus, and initiation of oral feeding, lower levels of sedation and more efficient mobilization $^{35}$.

Although the criteria for discharge were achieved earlier in TEA group, patients in this group went home at the same time as those from IV-PCA group. Previous studies ${ }^{4,10,18,25}$ and meta-analyses studying the effects of TEA on the length of stay as a primary outcome in colorectal surgery showed no difference in the length of stay ${ }^{3}$.

\section{Conclusion}

Solution of the problem of inadequacy of postoperative pain management does not actually lie in the usage of expensive medication or development and use of new techniques, but rather in optimal utilization of the already available drugs and clinically proven techniques. The results of this study clearly demonstrated the importance of TEA as a preferred method for postoperative pain control after major open colorectal surgery. Understanding the benefits of TEA by both anesthesiologists and surgeons, establishing analgesic protocols, use of pain scales and documentation of analgesia and adverse effects, and adequate patient monitoring are of crucial importance for implementation of TEA in routine practice.

\section{References}

1. Grass JA. The role of epidural anesthesia and analgesia in postoperative outcome. Anesthesiol Clin North Am. 2000;18: 407-28.

2. Wu CL, Cohen SR, Richman JM, et al. Efficacy of postoperative patient-controlled and continuous infusion epidural analgesia versus intravenous patient-controlled analgesia with opioids: a meta-analysis. Anesthesiology. 2005;103:1079-88.

3. Marret E, Remy C, Bonnet F; Postoperative Pain Forum Group. Meta-analysis of epidural analgesia versus parenteral opioid analgesia after colorectal surgery. Br J Surg. 2007;94:66573, https://doi.org/10.1002/bjs.5825.

4. Carli F, Trudel JL, Belliveau P. The effect of intraoperative thoracic epidural anesthesia and postoperative analgesia on bowel function after colorectal surgery: a prospective, randomized trial. Dis Colon Rectum. 2001;44:1083-9.

5. Pöpping DM, Elia N, Van Aken HK, Marret E, Schug SA, Kranke $P$, Wenk M, Tramèr MR. Impact of epidural analgesia on mortality and morbidity after surgery: systematic review and meta-analysis of randomized controlled trials. Ann Surg. 2014;259:1056-67, https://doi.org/10.1097/SLA.0000000000 000237.

6. Liu SS, Carpenter RL, Mackey DC, Thirlby RC, Rupp SM, Shine TS, Feinglass NG, Metzger PP, Fulmer JT, Smith SL. Effects of perioperative analgesic technique on rate of recovery after colon surgery. Anesthesiology. 1995;83:757-65.

7. Holte K, Kehlet H. Epidural anaesthesia and analgesia - effects on surgical stress responses and implications for postoperative nutrition. Clin Nutr. 2002;21:199-206, http://dx.doi.org/10. 1054/clnu.2001.0514.

8. Cummings KC $3^{\text {rd }}, \mathrm{Xu}$ F, Cummings LC, Cooper GS. A comparison of epidural analgesia and traditional pain management effects on survival and cancer recurrence after colectomy: a population-based study. Anesthesiology. 2012;116:797-806, https://doi.org/10.1097/ALN.0b013e31824674f6.

9. Jouve P, Bazin JE, Petit A, Minville V, Gerard A, Buc E. Epidural versus continuous preperitoneal analgesia during fasttrack open colorectal surgery: a randomized controlled trial. Anesthesiology. 2013;118:622-30, https://doi.org/10.1097/ ALN.0b013e3182800d94.

10. Carli F, Mayo N, Klubien K, Schricker T, Trudel J, Belliveau P. Epidural analgesia enhances functional exercise capacity and health-related quality of life after colonic surgery: results of a randomized trial. Anesthesiology. 2002;97:540-9.

11. Vogelaar FJ, Abegg R, van der Linden JC, Cornelisse HG, van Dorsten FR, Lemmens VE, Bosscha K. Epidural analgesia as- 
sociated with better survival in colon cancer. Int J Colorectal Dis. 2015;30:1103-7, https://doi.org/10.1007/s00384-0152224-8.

12. Snyder GL, Greenberg S. Effect of anaesthetic technique and other perioperative factors on cancer recurrence. Br J Anaesth. 2010;105:106-15, https://doi.org/10.1093/bja/aeq164.

13. Holler JP, Ahlbrandt J, Burkhardt E, Gruss M, Röhrig R, Knapheide J, Hecker A, Padberg W, Weigand MA. Peridural analgesia may affect long-term survival in patients with colorectal cancer after surgery (PACO-RAS-Study): an analysis of a cancer registry. Ann Surg. 2013;258:989-93, https://doi. org/10.1097/SLA.0b013e3182915f61.

14. Hasenberg T, Keese M, Längle F, Reibenwein B, Schindler K, Herold A, et al.,Fast-track' colonic surgery in Austria and Germany - results from the survey on patterns in current perioperative practice. Colorectal Dis. 2009;11:162-7, https://doi. org/10.1111/j.1463-1318.2008.01559.x.

15. Hasenberg T, Längle F, Reibenwein B, Schindler K, Post S, Spies C, Schwenk W, Shang E. Current perioperative practice in rectal surgery in Austria and Germany. Int J Colorectal Dis. 2010;25:855-63, https://doi.org/10.1007/s00384-010-0900-2.

16. Hannemann P, Lassen K, Hausel J, Nimmo S, Ljungqvist O, Nygren J, Soop M, Fearon K, Andersen J, Revhaug A, von Meyenfeldt MF, Dejong CH, Spies C. Patterns in current anaesthesiological perioperative practice for colonic resections: a survey in five northern-European countries. Acta Anaesthesiol Scand. 2006;50:1152-60, https://doi.org/10.1111/j.1399-6576. 2006.01121.x.

17. Zügel N, Bruer C, Breitschaft K, Angster R. Effect of thoracic epidural analgesia on the early postoperative phase after interventions on the gastrointestinal tract. Chirurg. 2002;73:262-8, https://doi.org/10.1007/s00104-001-0398-9.

18. Steinberg RB, Liu SS, Wu CL, Mackey DC, Grass JA, Ahlén $\mathrm{K}$, Jeppsson L. Comparison of ropivacaine-fentanyl patientcontrolled epidural analgesia with morphine intravenous patient-controlled analgesia for perioperative analgesia and recovery after open colon surgery. J Clin Anesth. 2002;14:571-7, http://dx.doi.org/10.1016/S0952-8180(02)00451-8.

19. Mann C, Pouzeratte Y, Boccara G, Peccoux C, Vergne C, Brunat G, Domergue J, Millat B, Colson P. Comparison of intravenous or epidural patient-controlled analgesia in the elderly after major abdominal surgery. Anesthesiology. 2000; 92:433-41.

20. Basse L, Hjort Jakobsen D, Billesbolle P, Werner M, Kehlet H. A clinical pathway to accelerate recovery after colonic resection. Ann Surg. 2000;232:51-7.

21. Kehlet H, Mogensen T. Hospital stay of 2 days after open sigmoidectomy with a multimodal rehabilitation programme. Br J Surg. 1999;86:227-30, https://doi.org/10.1046/j.1365-2168. 1999.01023.x.

22. Paulsen EK, Porter MG, Helmer SD, et al. Thoracic epidural versus patient-controlled analgesia in elective bowel resections. Am J Surg. 2001;182:570-7, http://dx.doi.org/10.1016/S00029610(01)00792-9.
23. Jørgensen H, Wetterslev J, Møiniche S, Dahl JB. Epidural local anaesthetics versus opioid-based analgesic regimens on postoperative gastrointestinal paralysis, $\mathrm{PONV}$ and pain after abdominal surgery. Cochrane Database Syst Rev. 2000;4:CD001893, https://doi.org/10.1002/14651858.CD001893.

24. Freise H, Van Aken HK. Risks and benefits of thoracic epidural anaesthesia. Br J Anaesth. 2011;107:859-68, https://doi. org/10.1093/bja/aer339.

25. Rimaitis K, Marchertiene I, Pavaklis D. Comparison of two different methods of analgesia. Postoperative course after colorectal cancer surgery. Medicina. 2003;39:129-37.

26. Ballantyne JC, Kupelnick B, McPeek B, Lau J. Does the evidence support the use of spinal and epidural anesthesia for surgery? J Clin Anesth. 2005;17:382-91, https://doi.org/10.1016/j. jclinane.2004.10.005.

27. Block BM, Liu SS, Rowlingson AJ, Cowan JA Jr, Wu CL. Efficacy of postoperative epidural analgesia: a meta-analysis. JAMA. 2003;290:2455-63, https://doi.org/10.1001/jama.290. 18.2455.

28. Rigg JR, Jamrozik K, Myles PS, Silbert BS, Peyton PJ, Parsons RW, Collins KS; MASTER Anaesthesia Trial Study Group. Epidural anaesthesia and analgesia and outcome of major surgery: a randomised trial. Lancet. 2002;359:1276-82, https:// doi.org/10.1016/S0140-6736(02)08266-1.

29. Zutshi M, Delaney CP, Senagore AJ, Mekhail N, Lewis B, Connor JT, Fazio VW. Randomized controlled trial comparing the controlled rehabilitation with early ambulation and diet pathway versus the controlled rehabilitation with early ambulation and diet with preemptive epidural anesthesia/analgesia after laparotomy and intestinal resection. Am J Surg. 2005; 189:268-72, https://doi.org/10.1016/j.amjsurg.2004.11.012.

30. Wu CL, Naqibuddin M, Fleisher LA. Measurement of patient satisfaction as an outcome of regional anesthesia and analgesia: a systematic review. Reg Anesth Pain Med. 2001;26:196-208, https://doi.org/10.1053/rapm.2001.22257.

31. Werawatganon T, Charuluxanun S. Patient controlled intravenous opioid analgesia versus continuous epidural analgesia for pain after intra-abdominal surgery. Cochrane Database Syst Rev. 2005;25:CD004088, https://doi.org/10.1002/14651858. CD004088.pub3.

32. Mann C, Ouro-Bang'na F, Eledjam JJ. Patient-controlled analgesia. Curr Drug Targets. 2005;6:815-9, https://doi.org/ 10.2174/138945005774574524.

33. Flisberg $\mathrm{P}$, Rudin A, Linner R, et al. Pain relief and safety after major surgery. A prospective study of epidural and intravenous analgesia in 2696 patients. Acta Anaesthesiol Scand. 2003; 47:457-65, http://onlinelibrary.wiley.com/enhanced/exportCitation/doi/10.1034/j.1399-6576.2003.00104.x.

34. Dolin SJ, Cashman JN. Tolerability of acute postoperative pain management: nausea, vomiting, sedation, pruritus, and urinary retention. Evidence from published data. Br J Anaesth. 2005; 95:584-91, https://doi.org/10.1093/bja/aei227.

35. Deiner S, Silverstein JH. Postoperative delirium and cognitive dysfunction. Br Anaesth. 2009;103:41-46, https://doi.org/10. 1093/bja/aep291. 


\section{Sažetak}

\section{USPOREDBA TORAKALNE EPIDURALNE ANALGEZIJE I INTRAVENSKE ANALGEZIJE KOJU KONTROLIRA BOLESNIK NAKON KOLOREKTALNIH ONKOLOŠKIH OPERACIJA}

\section{Radovanović, Z. Radovanović, S. Škorić-Jokić, M. Tatić, A. Mandić i T. Ivković-Kapicl}

Cilj istraživanja bio je usporediti torakalnu epiduralnu analgeziju (TEA) i intravensku analgeziju koju kontrolira bolesnik (intravenous patient-controlled analgesia, IV-PCA) nakon otvorenih kolorektalnih onkoloških operacija. Prospektivnim istraživanjem je obuhvaćeno šezdesetoro bolesnika podijeljenih u dvije skupine. U skupini IV-PCA ( $n=30)$ poslijeoperacijska analgezija je osigurana morfinom primijenjenim preko IV-PCA crpki, a u skupini TEA epiduralno primijenjenom smjesom levobupivakaina, fentanila i adrenalina $(n=30)$. Kao primarni ishod analiziran je oporavak crijevne peristaltike, a kao sekundarni kvaliteta poslijeoperacijske analgezije u mirovanju, kod kašlja i pri mobilizaciji. Analizirani su i zadovoljstvo bolesnika analgezijom, vrijeme provedeno izvan postelje, učestalost neželjenih učinaka i poslijeoperacijskih komplikacija te dužina liječenja u bolnici. Crijevna peristaltika je brže uspostavljena $(\mathrm{p}<0,001)$ i tekuća-kašasta prehrana ranije uvedena kod bolesnika u skupini TEA ( $\mathrm{p}<0,001)$. Poslijeoperacijska bol koju su tijekom 3 poslijeoperacijska dana bolesnici osjećali u mirovanju, kod kašlja i pri mobilizaciji $(\mathrm{p}<0,001)$ bila je značajno manjeg intenziteta u skupini TEA u usporedbi sa skupinom IV-PCA.TEA je omogućila bržu ranu mobilizaciju $(\mathrm{p}<0,005)$ i zadovoljstvo bolesnika poslijeoperacijskom analgezijom $(\mathrm{p}<0,001)$. Mučnina, sedacija i poslijeoperacijski delirij bili su rjeđi u skupini TEA ( $p<0,05, p<0.001$ i $p<0,05)$. TEA osigurava značajno bolju učinkovitost u usporedbi s IV-PCA nakon otvorenih kolorektalnih onkoloških operacija i ima pozitivan učinak na uspostavljanje crijevne peristaltike, početak peroralnog unosa, zadovoljstvo bolesnika i ranu mobilizaciju. Rezultati ovoga istraživanja dokazuju važnost primjene TEA kao prioritetne tehnike za analgeziju nakon opsežnih otvorenih kolorektalnih operacija.

Ključne riječi: Analgezija, epiduralna; Analgezija, pod kontrolom pacijenta; Kolorektalna kirurgija 